By ROBERT W. ORR

\title{
A Few Aspects of College Library Service
}

NUMBER of college librarians today
would rather measure the effectiveness of their library service in terms of books worn out or lost than in the number of volumes hoarded for posterity. This attitude denotes a growing emphasis on service to readers. It means, furthermore, the general acceptance of the principle that the chief function of libraries is to encourage, by all appropriate means available, greater use of books.

It is well that the protracted retention of the medieval viewpoint that libraries were museums intended for the safekeeping of books is fast disappearing. The character and complexity of the demands made on the modern college library constitute a perpetual challenge to the staffs to provide service adequate to meet these demands. Some of the factors responsible are: (I) greater use of library facilities in teaching, (2) more demands on the library by research workers who need easier access to the everincreasing volume of research publications, ${ }^{1}$ and (3) intensified efforts to stimulate reading in general, both on and off the campus.

Basically, of course, the library should support institutional programs. Characteristically, these programs for college libraries are principally teaching, research, and, in the case of land-grant college libraries, ${ }^{2}$ ex-

\footnotetext{
${ }^{1}$ Carlson, William Hugh. "The Research Worker and the Library." College and Research Libraries 7:291-300, October 1946.

2 The basic study about the libraries of the land grant institutions is the section by Charles $\mathrm{H}$. Brown in U.S. Office of Education. Survey of Land-grant Colleges and Universities. Bulletin 1930, no. 9, v. I, p. $609-714,1930$.
}

tension work. It is not possible, for obvious reasons, to outline a single program of service which would be applicable to all college libraries, but it is entirely possible and appropriate to discuss the opportunities for service which are open to them all,

Services rendered to undergraduate students pay the biggest dividends, potentially, of anything the library can do. Many students enter college without the remotest idea of how to use books or libraries or of the value to them of either. Yet they must be taught the use of both by the time of graduation to enable them to continue independently with an education just begun. The library in this respect renders an important service to the institution in the achievement of its educational objectives.

Undergraduate students go to the library for a number of reasons. ${ }^{3}$ One of the chief reasons is assigned readings. Assigned reading rooms, generally, are operated on a closed-shelf basis. Many members of the faculty, especially the younger ones, often prefer to have their books for assigned readings placed on open-shelf reserves. $\mathrm{Li}$ brarians have displayed timidity in doing this for fear the books would be stolen forthwith. Yet one library, on a trial basis, experimented with an open-shelf of reserve books pertaining to marriage, admittedly a severe test. Only two books out of a shelf of sixty disappeared in a period of three

3 These reasons are noted in a study by $H . V$. Gaskill, Ralph M. Dunbar, and Charles H. Brown. "An Analytical Study of the Use of a College Library." Library Quarterly 4:564-87, October 1934. 
months, a much lower rate of loss than that regularly suffered from the new book display.

Students should be encouraged to read for enjoyment and general information. Some librarians believe this habit should be instilled even if it is necessary to use detective stories as an initial inducement. As undergraduate students are not permitted to use the stacks, they must depend in their book selection upon the card catalog and displays of books. These displays should range in character from collections of detective stories and other popular materials to sets of abstracting journals and encyclopedias. The displays will vary in extent from a single shelf of books to special seminars and large undergraduate reading rooms. In conjunction with the book displays, bulletin boards should be used to display book jackets, book lists, posters about books and authors, and other materials. Even the front and editorial pages of the leading daily newspaper of the region will prove to be a star attraction if posted in a conspicuous place.

Eternal vigilance must be exercised by the library staff to guard against the possibility that undergraduate students may be slighted in favor of the faculty. It is easy enough to subscribe to the principle of equal consideration for both groups, according to their needs, but in practice it often does not work out that way. For example, the idea that a book should not be recalled from a professor for a student is untenable on any basis of fair and impartial service. Students are frequently justifiably sensitive about the privileges given to faculty which operate against their interests and convenience.

\section{Course in Use of Libraries}

The library should offer a compulsory course of instruction to all freshmen in the use of books and libraries. Compulsory is

JULY, 1947 a harsh word, but no other basis of offering the work will attract even the majority of freshman students to such a course. Preferably, the course should carry credit. It is illogical not to give credit, as the potential value of the course in the long run far outranks that of any other single course. The course should be taught by the library staff rather than by members of the English department who are frequently unfamiliar with the bibliographies, reference books, and other materials in the scientific fields. Furthermore, if the library is prepared to do it, an elective credit course specializing in bibliographic research should be offered to upperclassmen, preferably in cooperation with the subject departments.

Graduate students display little, if any, more knowledge than undergraduates of how to use books and libraries. It is not necessary here to argue the need for such ability. The library can make an important contribution to the graduate student's education by offering a course in bibliographic research open to all graduate students for either minor or major credit. The course should emphasize knowledge and use of important indexing and abstracting journals, practice in the preparation of bibliographies, and practice in correct citation of references to published and manuscript materials. The course should carry an hour's credit and should be taken during the first quarter, or semester, of the student's graduate work.

Some libraries find it mutually helpful to offer a special library seminar every fall, and perhaps once each summer, to which new graduate students, as well as recentlyappointed members of the faculty, are invited. Policies and services of the library can be discussed by the librarian, the reference librarian, and the order librarian. Brief information should be presented on the nature of the collections, policies followed in building up the collections, rules 
and procedures of the library in general, interlibrary loans, photoduplication service, and the like. Usually one of the most beneficial features of such a seminar is the question-and-answer period which follows the brief talks by members of the library staff.

Another service to graduate students is editorial supervision of theses. This is a logical service for the library to perform for a number of reasons. The necessary authority to enforce standards for theses should be delegated to the library by the graduate college. A manual setting forth recommendations and rules relative to bibliographic form, margin requirements, quality of paper, titles of figures and tables, and other matters should be prepared. Wellwritten theses reflect credit on the institution as well as on the author. The opposite is also true. Sometimes a graduate is rejected for employment because of a poorlywritten thesis submitted as a part of his application.

\section{Faculty Use Varies}

Members of the faculty use the library in varying degrees depending, illogically enough, on their respective fields of major interest, and irrespective of their teaching and research activities. Nearly all, however, need to be encouraged to make greater use of the library. Frequently the library can render no more important service than to induce members of the faculty to read more in fields other than their own.

Because it is imperative that members of the teaching and research faculties keep up with current developments in their fields, the library should make every effort to assist them in gaining ready access to periodicals and books. For example, procedures can be worked out for routing recent issues of important periodicals on a short-time loan basis to departments and divisions of the college. Members of the staffs of these de- partments and divisions can then go to seminar or reading rooms to consult these materials.

Every feasible way should be utilized to inform readers of the availability of new books. A new book shelf should be maintained near the loan desk, where faculty and students alike may browse among the recent acquisitions. A monthly list of recent accessions, arranged according to the classification scheme in use by the library, should be issued to all members of the faculty on a mailing list basis.

There should be close liaison between the library and the instructing staffs. Advantage should be taken of every opportunity to encourage and assist faculty members in developing teaching methods which involve the use of library facilities by students. Many instructors, for instance, welcome the chance to have a member of the library staff talk to their classes on library resources and their use in the preparation of student papers and reports. Such talks may remove one cause of any hesitancy on the part of the faculty members in requiring extensive use of the library by their students. In the assigned reading room the library can assist by providing ample numbers of materials, including photostats ${ }^{4}$ of items not available in the original editions. In this connection, it is quite appropriate for the library to keep a record of the circulation of assigned reading materials and to report to the faculty on books which are never, or seldom, used. Better service in the assigned reading room can be given if little-used publications are removed from the shelves,

\section{Assistance in Translating}

Assistance to readers who desire help with articles written in foreign languages is another logical service for the library, For

- Orr, Robert W. "Photostats in a College Library." College and Research Libraries 7:220-23, July 1946. 
example, the day is not far distant when research workers will have to find some means of reading the greatly increased volume of Russian scientific literature which is in prospect. Not many of them will have the time or inclination to learn the Russian language, especially older members of the faculty. Unless special journals carrying translations of Russian articles are published, translators must be made available. As members of the library staff, these translators could assist nearly all of the departments of the library with matters pertaining to the acquisition, processing, and circulation of material published in Russian. Their assistance to members of the faculty and to students for translating purposes could be available gratis when no more than a few minutes of time is required. Translation of whole articles could be handled on a fee basis. It is quite possible, furthermore, that these specialists in Russian could also cooperate with the department of modern languages in teaching one or more courses in Russian.

A great convenience to members of the faculty is the maintenance by the library of a campus messenger service for the purpose of delivering and picking up books from faculty offices. Unaccountably, there is on every campus a psychological hazard which oftentimes deters members of the faculty from going to the library for books, even if the library is merely across the street. The availability of messenger service in these instances may encourage faculty members to ask for and to return books to the library. If such a service is not possible, arrangements could be made for strategically-placed deposit boxes in different buildings into which books could be put for later pickup by the library.

\section{Off-Campus Service}

There are also off-campus readers who need library service. Inasmuch as the landgrant college is a publicly-supported institution, the library has an obligation to be of what service ${ }^{5}$ it can to the people residing in the area served by the agricultural extension service. Largely, such service will depend on the resourcefulness of the library staff as well as their willingness to make the added effort involved. The library can provide services to these people by the means of interlibrary loans, book talks, and reviews over the radio, ${ }^{6}$ and the assistance of an extension librarian. .

There are certain general library services available to all readers at public service desks which are best discussed as such. Interlibrary loan service, incoming and outgoing, is one of them. Over-the-counter loan desk service is another. Reference service is a third, and there are others.

The whole question of interlibrary loan service is in need of considerable study. This is attested to by the fact that very often it is referred to as the problem of interlibrary loans. Too often studies of this service take the form of discussions relative to details as to the best form for requests, how much bibliographical data should be included in the request, and the like. What should be determined are such considerations as: (I) what types of materials should be lent and to whom; (2) for what types of readers and for what purposes should libraries request loans; and (3) what alternatives to interlibrary loans are there.

Libraries should not borrow extensively to support institutional programs of research or instruction. Such material should be purchased. If the material is unavailable or if needed perhaps only once, photoduplica-

5 Wilson, Louis R. "The Role of the Land-Grant College in Rural Library Extension." Association of Land-Grant Colleges and Universities, Proceedings $52: 54-56,1938$.

'Orr, Robert W. "Radio Programs for Land-Grant College and University Libraries." College and Re. search Libraries $8: 234 \cdot 38$, July 1947. 
tions should be purchased or members of the faculty concerned should have their way paid to other libraries to consult such materials. It is often less expensive for an institution to pay the expenses of a faculty member to enable him to go to another library than for the library to buy expensive sets which may be used relatively few times. Even if the library can afford to purchase seldom-needed sets, there is a point beyond which the reason for having such publications is more esthetic than practical.

Libraries should not lend publications to other libraries two thousand or more miles distant when they are available nearby. Yet such requests are mailed every week by libraries which do not take the trouble to check the Union List of Serials. Photostats and microfilms as alternatives to a greater proportion of interlibrary loans should be given serious study.

\section{Over-the-Counter Loans}

Over-the-counter loans at the circulation desk is a service which all libraries should strive to keep at the peak of promptness and efficiency. As indicated by Brown, ${ }^{7}$ the library's reputation for service is largely gained by the quality of service available at the loan desk. This statement applies with equal force to the service given at the reference and assigned reading room desks.

The subject of loan desk service is too lengthy for even a summary here, but it should include: (I) prompt delivery of books to readers or an accounting of books not available; (2) notification of names of persons to whom books are charged and the dates the books are due; and (3) recall of books needed by other readers. The loan desk achieves this kind of service by doing such things as: (I) continuous reading of

\footnotetext{
"Brown, Charles H., and Bousfield, Humphrey G. "Circulation Work in College and University Li. braries." Chicago, American Library Association, 1933, p. $6 z$.
}

the shelves in the stacks; (2) regular inventory of the shelves; and (3) systematic study of the reasons why books requested are not found or accounted for. A library can gain a very good idea of the chief reasons why books are not located by checking the call slips or other records for books not found the previous day. It is taken for granted, of course, that appropriate corrective steps will be taken to remedy all weak points brought to light.

The resources needed in the reference department for prompt, efficient service cheerfully rendered are a staff of capable assistants and a reference desk conveniently located in relation to the telephone, card catalog, loan desk, principal abstracting and indexing journals, and reference books. The responsibility of monitoring the reference room should be delegated to clerical assistants. Reference librarians cannot perform their work to the best advantage if they must observe the deportment in the room and be alerted at all times to swoop down on offenders.

\section{Atmosphere Is Important}

The atmosphere at the reference desk should be one which will invite questions from readers. Students are notoriously timid about approaching any librarian at a public service desk who has a stern visage and unbending manner. Assistants at the reference desk should be able to meet the public easily and to give an impression of interest in the questions put to them. To be avoided at all costs are assistants at the reference desk who betray their feeling of disinterest in questions which they consider to be trivial. Readers may forgive mistakes; they will seldom forget discourtesies. Members of the library staff who have specialized knowledge in subject fields should be available to assist research workers.

The bibliography which is most frequent- 
ly used by the reference staff and by users of the library is the card catalog. The ways in which the (card catalog/can be made usable have been discussed so many times that it is not necessary to make a careful exposition of them here. However, these points are especially important: (I) separation of card catalog into author-title and subject sections; (2) liberal use of analytical entries, not only for important series, but for selected textbooks in order to bring out essential topics not otherwise adequately represented in the catalog; (3) liberal use of added entries and references in the author-title section; (4) liberal use of subdivisions in the subject section, especially to denote abstracts, bibliographies, and special features; (5) division of large sections of cards in the subject section into chronological groupings or according to some other basis; (6) placement of cards in authortitle section for recent editions ahead of those for earlier ones; (7) use of modern terminology for subject headings,

Finally, the librarian himself should take an active part in the operation of the li- brary. It is apparently fashionable today to appoint a head of the public services and a head of the technical processes. In the case of smaller libraries just what this is supposed to free the librarian to do is not always clear. In times past some librarians have functioned-if that is the word for it -in ivory towers. They have preferred to spend their time on matters of policy, the work of professional associations, or with certain hobbies such as the study and purchase of old and rare books.

The librarian cannot isolate himself fròm the day-to-day administrative minutiae and be certain that the library has the same impetus to strive for topnotch service. $\mathrm{He}$ should spend a part of his time at the various public service desks and in the departments of the so-called technical processes. If the task of administering the library is so demanding as to preclude such activities, it is quite possible that the librarian has failed to go far enough in arranging for members of the staff to participate administratively and responsibly in the library's affairs. 